\title{
Is there evidence that Kudoa septempunctata can cause an outbreak of acute food poisoning?
}

\author{
Young-Bae Chung ${ }^{1}$, Jong-Myon Bae ${ }^{2}$ \\ 'Department of Parasitology, Jeju National University School of Medicine, Jeju, Korea; ${ }^{2}$ Department of Preventive Medicine, Jeju National \\ University School of Medicine, Jeju, Korea
}

\begin{abstract}
After publishing results of a study that revealed diarrheagenic and emetic activity in 4-5-day old mice infected with Kudoa septempunctata (K. septempunctata) spores, the Korea Centers for Disease Control and Prevention reported 11 events of "Kudoa food poisoning" in 2015. The epidemiological design of the previous study was descriptive rather than analytical; therefore, this study aimed to further investigate the pathogenicity of K. septempunctata. Academic articles showing evidence of the pathogenicity of K. septempunctata were searched via PubMed using the citation discovery tool. Information regarding the kinds of experimental animals and inoculum spores used, as well as study results were extracted. Four articles evaluating the pathogenicity of Myxospran parasites were selected; the first article suggested the pathogenicity of $K$. septempunctata, while the remaining three articles reported no abnormal symptoms or histopathologic changes. Our findings indicate that there is weak evidence supporting the pathogenicity of $K$. septempunctata. Further studies evaluating the pathogenicity of $K$. septempunctata are needed urgently.
\end{abstract}

KEY WORDS: Etiology, Virulence, Food parasitology, Parasitic intestinal diseases, Myxozoa

\section{INTRODUCTION}

A new parasite was discovered in aquacultured olive flounders (Paralichthys olivaceus) in Jejudo, South Korea (hereafter Korea), in 2010 and was named Kudoa septempunctata (K. septempunctata) [1]. In December 2012, the Ministry of Health, Labour and Welfare in Japan announced that K. septempunctata is the causative agent of acute food poisoning and thereafter named the outbreak of the foodborne disease "Kudoa food poisoning" [2,3].

In 2015, Centers for Disease Control and Prevention in Korea conducted tests for K. septempunctata infection using vomit and fecal samples of patients with acute food poisoning symptoms who had a history of sliced, raw olive flounder consumption. released

\section{Correspondence: Jong-Myon Bae}

Department of Preventive Medicine, Jeju National University School of Medicine, 102 Jejudaehak-ro, Jeju 63243, Korea

E-mail:jmbae@jejunu.ac.kr

Received: Dec 11, 2016 / Accepted: Jan 30, 2017 / Published: Jan 30, 2017

This article is available from: http://e-epih.org/

(C) This is an open-access article distributed under the terms of the Creative Commons Attribution License (http://creativecommons.org/licenses/by/4.0/), which permits unrestricted use, distribution, and reproduction in any medium, provided the original work is properly cited.

(C) 2017, Korean Society of Epidemiology case reports on "Kudoa food poisoning", detailing its characteristics [4]. The case reports identified K. septempunctata as the causative agent based on the fact that it was detected in each of 11 events analyzed. Table 1 shows a summary of the main epidemiological characteristics of patients with food poisoning possibly attributed to K. septempunctata.

However, since case reports are descriptive rather than analytic epidemiologic methods, which suggest hypotheses only instead of identifying causes, respectively, the results of the above-mentioned case reports cannot prove $K$. septempunctata as the causative agent of an acute outbreak of "Kudoa food poisoning." The results do however, show that among cases with acute food poisoning, the $18 \mathrm{~S}$ ribosomal RNA gene (rRNA) of K. septempunctata was detected [3]. The current study aimed to summarize the evidences regarding the pathogenicity of $K$. septempunctata, found in P. olivaceus of Jejudo origin, which has been reported as the causative agent of an outbreak of acute food poisoning.

\section{EVALUATION OF THE RELATED EVIDENCES}

A PubMed citation discovery tool was used to select information from "cited articles" and "similar articles" related to the pathogenicity of K. septempunctata [5]. From the article by Kawai et al. [2], which first reported on the pathogenicity of K. septempunctata 
to cause acute food poisoning, a list of 11 cited articles and $115 \mathrm{sim}$ ilar articles was obtained through the PubMed search on December 11, 2016.

Using the list, we examined whether the related abstracts dealt with the pathogenicity of $K$. septempunctata to cause an outbreak of acute food poisoning; 2 [6,7] of the 11 cited articles and 1 [8] of the 115 similar articles were selected. Therefore, a total of four articles, including the article by Kawai et al. [2] were included to summarize the evidence of the pathogenicity of K. septempunctata. The types and numbers of experimental animals and inoculum spores, and the findings from the four articles were summarized in Table 2.

With the exception of the article by Kawai et al. [2], which reported on the pathogenicity of K. septempunctata, the articles [6-8] did not report any cases of diarrhea and vomiting. Although the subjects and experimental methods in the study by Jang et al. [7] were the same as those in the study by Kawai et al. [2], the results differed. Kawai et al. [2] were Japanese and claimed that the pathogenicity of K. septempunctata caused the outbreak of acute food poisoning; the authors of the other studies were Chinese and Korean.

Table 1. Epidemiological characteristics of cases with food poisoning $(n=94)$ detected by Kudoa septumpunctata in 2015, in Korea ${ }^{1}$

\begin{tabular}{lc}
\hline Characteristics & $\mathrm{n}(\%)$ \\
\hline $\begin{array}{l}\text { Symptom occurrence (\%) } \\
\text { Mean (range) }\end{array}$ & $61(21-100)$ \\
$\begin{array}{l}\text { Incubation time (hr) } \\
\text { Mean (range) }\end{array}$ & $2(1-15)$ \\
Clinical symptoms ${ }^{2}$ & \\
Diarrhea & $78(82.9)$ \\
Vomiting & $78(82.9)$ \\
Abdominal pain & $60(63.8)$ \\
Nausea & $56(59.5)$ \\
Chillness & $55(58.5)$ \\
Fever & $35(37.2)$ \\
Headache & $6(6.0)$ \\
\hline
\end{tabular}

'Source from: Korea Centers for Disease Control and Prevention. Case reports of Kudoa food poisoning in 2015; 2016 [4].

${ }^{2}$ Responses are not mutually exclusive.

\section{CONCLUSION AND SUGGESTION}

Upon examination of the 4 studies, it was determined that the results of the study in Japan supported the pathogenicity of K. septempunctata to cause an outbreak of acute food poisoning, while the studies in Korea and China opposed it. Kawai et al. [2] reported that diarrhea was induced in 4-5-day-old mice infected with $K$. septempunctata; however, the remaining studies used the same methodology and showed conflicting results $[7,8]$. Overall, our findings suggest that the evidence for the pathogenicity of K. septempunctata is still weak, in light of the currently available literature. There is a lack of evidence to use the term "Kudoa food poisoning," and the pathogenicity of K. septempunctata should be reconsidered. There is an urgent need for an international forum to discuss these discrepant results.

Discrepant results have been reported for the intestinal permeability of K. septempunctata in addition to its pathogenicity. In 2013, Ohnishi et al. [9] reported that K. septempunctata invaded the human intestinal epithelia monolayer, whereas Ahn et al. [6] did not observe such a phenomenon. Additionally, this topic should also be discussed in detail at an international forum.

In 2016, Kasai et al. [10] reported that three Kudoa species, including K. septempunctata, are present in fish in natural waters, in addition to aquacultured $P$. olivaceus. The intermediate hosts of $K$. septempunctata have not been identified until now and studies that consider host lifecycle are needed.

To date, the experimental evidence of the pathogenicity of $K$. septempunctata is inconsistent; there is a lack of scientific validity to support the epidemiologic causality between K. septempunctata and acute food poisoning based solely on the results of case reports. Hill's criteria are used widely as the standard measure of epidemiologic causality [11]; however, it is not feasible to apply the criteria to case studies with no control group. This is supported by the epidemiologic finding in which it was argued that the measles, mumps, and rubella vaccination was associated with autism in case reports of 12 pediatric cases with autism [12]. This event had great repercussions on infection prevention policies; however, it was concluded that there was no association between the vaccination and autism [13]. Further analytic and epidemiologic studies, such as case-

Table 2. Summary of the evidence related to the pathogenicity of Myxosporean parasites

\begin{tabular}{|c|c|c|c|c|c|}
\hline $\begin{array}{c}\text { First author (public } \\
\text { year) [Reference] }\end{array}$ & $\begin{array}{l}\text { Experimental } \\
\text { animal }\end{array}$ & Inoculum spores & $\begin{array}{l}\text { Inoculation } \\
\text { route }\end{array}$ & Outcome & Results \\
\hline Kawai (2012) [2] & $\begin{array}{l}4-5-d \text { old ddY } \\
\text { mouse }\end{array}$ & $\begin{array}{l}\text { Kudoa septempunc- } \\
\text { tata }\end{array}$ & Oral & Bowel movements and FAR & $\begin{array}{l}\text { Showing diarrheagenic activity }(11 / 17) \\
\text { and significantly higher FAR }\end{array}$ \\
\hline Ahn (2015) [6] & $\begin{array}{l}\text { 6-wk old BALB/c } \\
\text { mice }\end{array}$ & $\begin{array}{l}\text { Kudoa septempunc- } \\
\text { tata }\end{array}$ & Oral & $\begin{array}{l}\text { Bowl movements and histo- } \\
\text { pathological examination }\end{array}$ & $\begin{array}{c}\text { No significant diarrhea }(0 / 32) \text { and } \\
\text { histopathologic changes }(0 / 24)\end{array}$ \\
\hline Jang (2016) [7] & $\begin{array}{l}\text { 4-5-d old ddY } \\
\text { mouse }\end{array}$ & $\begin{array}{l}\text { Kudoa septempunc- } \\
\text { tata }\end{array}$ & Oral & Bowel movements and FAR & $\begin{array}{l}\text { No watery stool form }(0 / 20) \text { and no } \\
\text { significant variations in FAR }\end{array}$ \\
\hline Guo (2015) [8] & $\begin{array}{l}\text { 4-5-d old BALB/c } \\
\text { suckling mice }\end{array}$ & $\begin{array}{l}\text { Myxobolus hongh- } \\
\text { uensis }\end{array}$ & Oral & $\begin{array}{l}\text { Bowel movements, FAR, and } \\
\text { histopathology }\end{array}$ & $\begin{array}{l}\text { No significant change of FAR, no } \\
\text { abnormal stool form }(0 / 25) \text { and no } \\
\text { evidence of inflammation }(0 / 25)\end{array}$ \\
\hline
\end{tabular}

ddY, Deutschland, Denken, and Yoken; FAR, fluid accumulation ratio; BALB/c, albino, laboratory bread strain of the house mouse. 
control studies or cohort studies, will provide evidence for evaluating epidemiologic causality in future.

In conclusion, the authors of the present manuscript highlight that the present argument about the pathogenicity of K. septempunctata as the cause of an outbreak of acute food poisoning is solely based on the results of animal experiments with low reproducibility. Additionally, they do not support the argument that $K$. septempunctata does not cause food poisoning.

\section{CONFLICT OF INTEREST}

The authors have no conflicts of interest to declare for this study.

\section{SUPPLEMENTARY MATERIAL}

Supplementary material (Korean version) is available at http: // www.e-epih.org/.

\section{ORCID}

Young-Bae Chung: http://orcid.org/0000-0001-8562-7467; JongMyon Bae: http://orcid.org/0000-0003-3080-7852

\section{REFERENCES}

1. Matsukane Y, Sato H, Tanaka S, Kamata Y, Sugita-Konishi Y. Kudoa septempunctata n. sp. (Myxosporea: Multivalvulida) from an aquacultured olive flounder (Paralichthys olivaceus) imported from Korea. Parasitol Res 2010;107:865-872.

2. Kawai T, Sekizuka T, Yahata Y, Kuroda M, Kumeda Y, Iijima Y, et al. Identification of Kudoa septempunctata as the causative agent of novel food poisoning outbreaks in Japan by consumption of Paralichthys olivaceus in raw fish. Clin Infect Dis 2012;54:10461052.

3. Sugita-Konishi Y, Sato H, Ohnishi T. Novel foodborne disease associated with consumption of raw fish, olive flounder (Paralichthys olivaceus). Food Saf 2014;2:141-150.
4. Centers for Disease Control and Prevention. Case reports of Kudoa food poisoning in 2015; 2016 [cited 2016 Dec 11]. Available from: http://cdc.go.kr/CDC/notice/CdcKrTogether0302.jsp?menuIds = HOME001-MNU1154-MNU0005-MNU0088\&cid = 71877 (Korean).

5. Bae JM, Kim EH. Citation discovery tools for conducting adaptive meta-analyses to update systematic reviews. J Prev Med Public Health 2016;49:129-133.

6. Ahn M, Woo H Kang B, Jang Y, Shin T. Effect of oral administration of Kudoa septempunctata genotype ST3 in adult BALB/c mice. Parasite 2015;22:35.

7. Jang Y, Ahn M, Bang H, Kang B. Effects of Kudoa septempunctata genotype ST3 isolate from Korea on ddY suckling mice. Parasite 2016;23:18.

8. Guo Q, Jia L, Qin J, Li H, Gu Z. Myxozoans and our dinner table: pathogenicity studies of Mmyxobolus honghuensis (Myxosporea: Bivalvulida) using a suckling mice model. Foodborne Pathog Dis 2015;12:653-660.

9. Ohnishi T, Kikuchi Y, Furusawa H, Kamata Y, Sugita-Konishi Y. Kudoa septempunctata invasion increases the permeability of human intestinal epithelial monolayer. Foodborne Pathog Dis 2013; 10:137-142.

10. Kasai A, Li Y, Mafie E, Sato H. New host records of monacanthid fish for three Kudoa spp. (K. septempunctata, K. thyrsites, and K. shiomitsui) prevalent in the olive flounder (Paralichthys olivaceus), with the description of K. parathyrsites n. sp. from a black scraper (Thamnaconus modestus). Parasitol Res 2016;115:27412755.

11. Rothman KJ, Greenland S. Causation and causal inference in epidemiology. Am J Public Health 2005;95 Suppl 1:S144-S150.

12. Napier G, Lee D, Robertson C, Lawson A, Pollock KG. A model to estimate the impact of changes in MMR vaccine uptake on inequalities in measles susceptibility in Scotland. Stat Methods Med Res 2016;25:1185-1200.

13. Robertson DJ, Sandler RS. Measles virus and Crohn's disease: a critical appraisal of the current literature. Inflamm Bowel Dis 2001; 7:51-57. 